\title{
Analysis of Prolactin Gene Exon 4 Diversity in Peking, White Mojosari, and Peking White Mojosari Crossbreed
}

\author{
M. Indriati ${ }^{\mathrm{a},{ }^{*},}$, C. Sumantri ${ }^{\mathrm{b}}$, \& $^{\text {\& T. Susanti }}{ }^{\mathrm{c}}$ \\ aStudy Program of Animal Production and Technology, Faculty of Animal Science, Graduate School, \\ Bogor Agricultural University \\ ${ }^{\mathrm{b}}$ Department of Animal Production and Technology, Faculty of Animal Science, Bogor Agricultural University \\ Jalan Agatis, Kampus IPB Darmaga Bogor 16680, Indonesia \\ Indonesian Research Institute for Animal Production \\ Jalan Veteran III, Desa Banjarwaru, Ciawi - Bogor 16002, Indonesia \\ (Received 05-06-2014; Reviewed 16-07-2014; Accepted 03-07-2015)
}

\begin{abstract}
Genetic marker linked to loci reproductive traits could be used to increase an effectiveness of improvement in animal breeding. Association between DNA polymorphism and a trait could be considered as candidate genetic marker for marker assisted selection (MAS) programs. Prolactin (PRL) is one of polypeptide hormones secreted by anterior pituitary gland in vertebrates. PRL plays an important role in onset of poultry incubation and brooding behavior. The aim of this study was to investigate the diversity of prolactin gene and to characterize the type of mutation in partial intron 3, intron 4 and exon 4 of duck prolactin gene. Blood extraction was collected from 168 ducks consisted of 19 Peking, 36 Mojosari, and 113 Peking White Mojosari (Peking Mojosari putih) ducks. Polymerase chain reaction of fragment prolactin gene exon 4 and partial intron 3 and 4 have been successfully amplified with length of base pair were $496 \mathrm{bp}$. A total of $30 \mu \mathrm{L}$ PCR product from each sample were sequenced for forward sequence using BIOTRACE 3730 by First Base Company, Malaysia. Alignment analysis found six SNP consisted of g.3941T>G, g.3975C $>$ A, g.4110T>C, INDEL 3724A, INDEL 34031, and INDEL 3939A. Analysis of SNP frequency result indicated mutation of INDEL 3724A, g.3941T>G, g.3975C $>\mathrm{A}$, INDEL 4031A and g.4110T $>\mathrm{A}$ in duck sample were polymorphic and INDEL 3939A were monomorphic.
\end{abstract}

Key words: prolactin gene, duck, SNP, mutation, PMp duck

\section{ABSTRAK}

Marka genetik yang dikaitkan pada lokus pembawa sifat reproduksi dapat digunakan untuk meningkatkan efektivitas kegiatan pemuliaan ternak. Ditemukannya asosiasi antara polimorfisme DNA dengan suatu sifat dapat dijadikan sebagai kandidat penanda genetik pada program seleksi (marker assisted selection/MAS programe). Prolaktin (PRL) merupakan salah satu hormon polipeptida yang disekresikan oleh kelenjar pituitari anterior pada vertebrata. PRL berperan penting pada pengaturan waktu pertama kalinya masa inkubasi dan perilaku rontok bulu pada unggas. Tujuan penelitian ini adalah untuk karakterisasi polimorfisme gen prolaktin ekson 4, partial intron 3 dan partial intron 4 pada itik. Sampel darah diperoleh dari 168 itik yang terdiri atas 19 ekor itik Peking, 36 ekor itik Mojosari putih dan 113 ekor itik Peking Mojosari putih (PMp). Polymerase chain reaction (PCR) fragmen gen prolaktin ekson 4 dan partial intron 3 dan 4 berhasil diamplifikasi dengan panjang pasang basa sebesar $496 \mathrm{bp}$. Sebanyak $30 \mu \mathrm{L}$ dari setiap produk PCR disekuensing menggunakan BIO TRACE 3730 dari perusahaan First Base, Malaysia. Analisis pensejajaran terhadap fragmen DNA menghasilkan 6 SNP yang terdiri atas g.3941T>G, g.3975C $>\mathrm{A}$, g.4110T>C, INDEL 3724A, INDEL 4031A dan INDEL 3939A. Hasil analisis frekuensi SNP menunjukkan bahwa INDEL 3724A, g.3941T>G, g.3975C >A, INDEL 4031A, dan g.4110T>A pada titik mutasi itik sampel adalah polimorfik sedangkan titik mutasi INDEL 3939A adalah monomorfik.

Kata kunci: gen prolaktin, itik, SNP, mutasi, itik PMp

${ }^{*}$ Corresponding author:

E-mail: marlinda.indriati87@gmail.com 


\section{INTRODUCTION}

Nowadays people attracted to consume diversi livestock products, such as duck meat. The increasing demand of duck meat for consumption during the year causes the increasing of Day Old Duck (DOD) demand, but it is not balanced with the increase of qualified duck breed availability and its production. In Indonesia, the production of duck meat product is still low compared to other countries in Asia. According to FAO (2013), the total production of duck meat in Asia in 2010 reached 3,330,600 tons (from 8 countries in Asia). China is the biggest producer of duck meat with the production rate $2,736,300$ tons. Indonesia produces only 27,900 tons; this production is the smallest than other countries in Asia, such as Malaysia which has produced 116,300 tons, Bangladesh 41,500 tons, India 37,700 tons, Myanmar 83,600 tons, Thailand 80,000 tons, and Vietnam 74,600 tons (FAO, 2013).

One effort to increase production of local duck was by cross breeding between different breeds of duck, for example in this experiment a male Peking duck was crossed with female white Mojosari duck conducted by artificial insemination and resulted Peking Mojosari putih (PMp) duck. The special characteristics of PMp duck were having white feather so that carcass colour also clean, body weight $2-2.5 \mathrm{~kg}$ at age $10 \mathrm{wk}$, first age to lay eggs 5.5-6 mo, and the average egg produced at 6 mo was $73 \%-78 \%$ (IRIAP, 2011). The problems of the Indonesian local duck breeds can be solved by the improvement of duck productivity through selection at DNA level. Genetic markers linked to the chromosome locus that influence duck reproduction trait can improve the effectiveness and rapidity of duck productivity. When the relationship between gene diversity and reproductive traits are found, the gene diversity (polymorphisms) can be used as a candidate of genetic marker for marker assisted selection (MAS) program. According to Muladno (2010), identification of DNA diversity associated with quantitative traits could be used as a base for implementing marker assisted selection (MAS) program.

Genes that have significant effects on egg production are prolactin and prolactin receptor gene (Wang et al. 2011). This hormone is mainly synthesized in the anterior pituitary (Cui et al. 2006; Jiang et al. 2009; Wang et al. 2009) by lactotroph cells. Structure of duck prolactin gene is successed cloned and sequenced. The duck prolactin gene is $6.33 \mathrm{~kb}$ in length and is composed of five exons and four introns, encoding 229 amino acids, and the duck prolactin cDNA shares $92.0 \%, 91.7 \%$, and $91.4 \%$ sequence homology to chicken, turkey, and quail prolactin, respectively (Kansaku et al. 2005) with three disulfide bridges between six cysteines, and has a molecular weight of $23 \mathrm{kDa}$ (Kansaku et al. 2008).

The biological actions of prolactin mediated by a prolactin receptor (PRLR), with growth hormone receptor (GHR) prolactin share high degree of structural similarity and belongs to the class I cytokine receptor superfamily. The activation of prolactin receptor by prolactin binding can initiate the intracellular 59 signaling cascades, including activation of the intracellular 60 JAK2-STAT5 signaling pathway (Bu et al., 2013).
Sequence of prolactin gene is able to provide basic data to investigate the gene influence on traits of reproduction and production. Analysis of association between gene diversity and reproduction traits revealed showed significant result. Chang et al. (2012) reported that there were two mutations occurred in non-coding regions of intron 4 there are g.3941T>G and g.3975C $>$ A. Association analysis showed that each SNP was associated with at least one duck reproductive traits. The aim of this study was to identify the diversity of prolactin gene of Peking duck, white Mojosari duck and PMp duck and to find out genetic markers as a basic to do selection program in DNA level.

\section{MATERIALS AND METHODS}

\section{Sample Sources}

Ducks used in the research were from Research Institute for Animal Production Ciawi Bogor. There were 113 PMp (Peking Mojosari putih) consisted of 15 male ducks and 98 female ducks; 19 Peking ducks consisted of 4 male ducks and 15 female ducks; and 36 white Mojosari ducks consisted of 12 male ducks and 24 female ducks. All ducks were simultaneously maintained in an individual cage and in the same condition of management housing and feeding.

\section{Blood Samples}

Blood samples collected from Peking, white Mojosari, and PMp duck. All ducks were kept in the research cage of Indonesian Research Institute for Animal Production (Balai Penelitian Ternak) Ciawi-Bogor. Blood samples were taken $1 \mathrm{~mL}$ and collected in 1.5 mL Eppendorf tube containing EDTA as anticoagulant. Samples were processed in a same day when they were extracting. For the isolation, DNA was stored at temperature $-4^{\circ} \mathrm{C}$ for subsequent use.

\section{Primer Prolactin Gene}

The use of primer exon 4 consisted of forward 5- CTG CAT CTG TGG ACA TTG CT -3 and reverse 5GAA GCA GGT TTG GGA GTA CG -3. Primer designed base on duck prolactin gene (code access AB 158611.1) using primer 3 . The position of annealing primers of the prolactin gene sequences exon 4 is showed in Figure 1.

\section{DNA Extraction}

The method of extraction DNA from fresh blood was Genomic DNA Mini Kit (GeneAidTM DNA Isolation Kit). Purity of DNA was tested twice, first using spectrophotometer and second based on visualization result from electrophoresis (Sambrook et al., 1989).

\section{DNA Quality Test}

The quality and quantity of DNA in an organism were determined by using a spectrophotometer. DNA qualities were measured by 260 and $280 \mathrm{~nm}$ wave- 


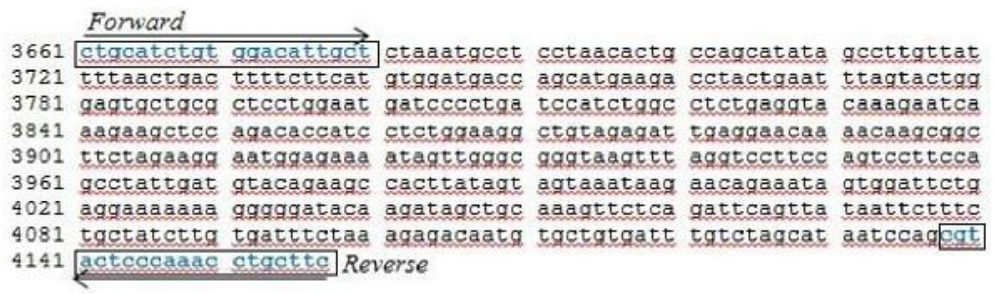

Figure 1. Primer position of PCR product prolactin gene (GenBank access number AB158611). Note: The sequnce prolactine inside the border shows primer prolactine gene.

lengths. Formula of DNA concentration $=\mathrm{A}_{260} \times \mathrm{DF} \times 50$. $\mathrm{DF}$ is dilution factor.

\section{Polymerase Chain Reaction Method}

The PCR reaction was made as much $35 \mu \mathrm{M}$ consisted of solution $0.7 \mu \mathrm{M}$ of primer exon $4.1 \mu \mathrm{L}$ DNA, $17.5 \mu \mathrm{L}$ KAPA $2 \mathrm{G}$ master mix and $16.8 \mu \mathrm{L}$ PCR grade water. KAPA $2 \mathrm{G}$ master mix taq consisted of DNA polymerase, PCR buffer, $\mathrm{MgCl}_{2}$ and dNTPs were ready to use. DNA amplification was placed in the Applied Biosystems PCR machine with temperature condition for pre denaturation was $95^{\circ} \mathrm{C}$ for $5 \mathrm{~min}, 35$ cycles for denaturation stage $95^{\circ} \mathrm{C}$ for $10 \mathrm{~s}$, annealing at temperature $60^{\circ} \mathrm{C}$ for $20 \mathrm{~s}$, elongation at temperature $72^{\circ} \mathrm{C}$ for 30 $\mathrm{s}$, and elongation at temperature $72^{\circ} \mathrm{C}$ for $5 \mathrm{~min}$ in one cycle. After the cycle ends, it was continued at storage temperature $4^{\circ} \mathrm{C}$. The result of PCR amplification was checked by agarose gel electrophoresis $1.5 \%$.

\section{Electrophoresis and Analysis of Nucleotide Composition DNA}

The first step for electrophoresis was preparing $1.5 \%$ agarose gel by weighting $0.45 \mathrm{~g}$ agarose and dissolved in $30 \mathrm{~mL}$ of solution $0.5 \mathrm{X}$ TBE buffer $(1 \mathrm{M}$ Tris, 0.9 M Boric acid, 0.01 M EDTA pH 8.0) and then heated in microwave for $\pm 3 \mathrm{~min}$. After agarose was dissolved (clear look), it was cooled by using stirrer and was added with florosafe (component substation of ethidium bromide which non carcinogen) $2 \mu \mathrm{L}$. The solution was put into a tray which contain of a comb as wells for DNA samples and let them stand for $\pm 15 \mathrm{~min}$. The $2 \mu \mathrm{L}$ samples was put into wells in the next step and the process of electrophoresis was begun at a voltage 100 volts for $45 \mathrm{~min}$. Each banding pattern which forn visualized on UV transiluminator. All samples would show different band in gel which had undertaken the purification and amplification, then PCR product was sequenced on a BIO TRACE 3730 DNA Analyzer from First Base Company, Malaysia.

\section{Data Analysis}

Analysis of homology. Analysis homology of samples sequence with database reference and others avian species in gene bank were using Basic Local Alignment Search Tool (BLAST) (www.ncbi.nhl.nih.ov./B:AST). The percentage of homology showed in identity value for each duck sample.
Analysis of nucleotide base composition. Composition of nucleotide base analysis used Bio Edit Sequence Alignment Editor (Hall, 1999) and Molecular Evolutionary Genetics Analysis (Tamura et al., 2007).

Identification of the SNP polymorphism. SNP (Single nucleotide polymorphisms) identified in this research was obtained by comparing the alignment of each duck sample prolactin sequence to Anas platyrhynchos sequence (Gen Bank: AB15861) by using Molecular Evolutionary Genetics Analysis (MEGA4) (Tamura et al., 2007) and the result of electropherogram for every ducks using Bio Edit Sequence Alignment Editor.

\section{RESULTS AND DISCUSSION}

\section{Prolactin Gene Amplification}

PCR results were visualized on $1.5 \%$ agarose agar as presented in Figure 2. The results showed that the visualization of the product amplification of prolactin gene exon 4 and partial intron 3 and 4 was $496 \mathrm{bp}$. The result was consistent with the results of annealing the target region at position 3661-4157 bp. Identification of genotypes of prolactin gene in PMp, Peking, and white Mojosari duck were done by identifying each band appearance compared with markers. Li et al. (2009) reported that prolactin gene amplification was obtained by condition PCR at temperature preheating $95^{\circ} \mathrm{C}$, followed by denaturation $94^{\circ} \mathrm{C}$, annealing $58^{\circ} \mathrm{C}$, and extension $72^{\circ} \mathrm{C}$. Other research conducted by Chang et al. (2012) stated that prolactin gene amplification of exon 4 with condition PCR used preheating $94^{\circ} \mathrm{C}$, followed by denaturation $94^{\circ} \mathrm{C}$, annealing $58^{\circ} \mathrm{C}$, and extension $72^{\circ} \mathrm{C}$.

Polymorphisms in this study were detected by polymerase chain reaction (PCR) and were verified by DNA sequencing, the result of trial error concluded that amplification could success at temperature annealing $60^{\circ} \mathrm{C}$ for $20 \mathrm{~s}$. The success of duck's prolactin gene fragment amplification is determined by the condition of primary annealing on genomic DNA (target gene), PCR reagents, and temperature condition of thermal cycler machine.

\section{Characteristic of Prolactin Gene}

Homology of prolactin gene. Basic Local Alignment Search Tools (BLAST) found the regions of local similarity between protein or nucleotide sequence. This program compared nucleotide or protein sequence to sequence 


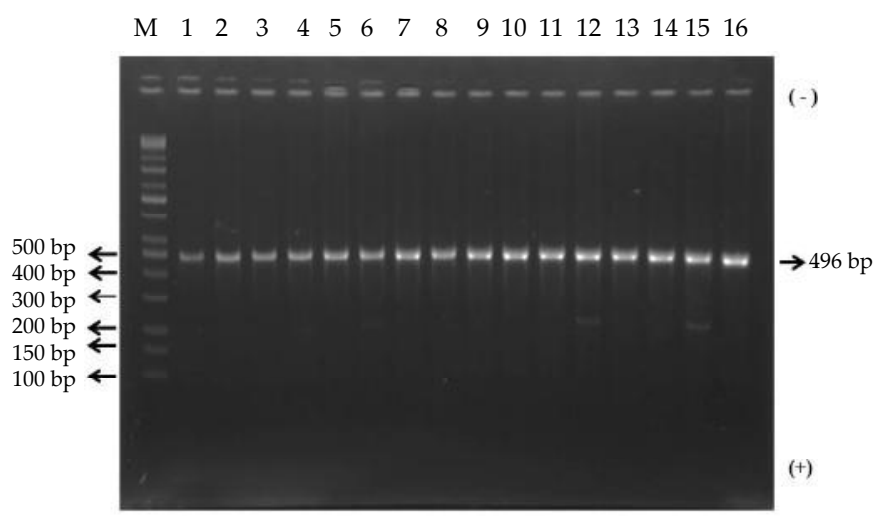

Figure 2. Visualization of prolactin gene fragment amplification exon 4. Note: $M=$ Marker, no 1-16= number of sample.

in a database and calculated the statistical significant of the matches (Wheeler \& Baghwat, 2007). The result of analysis of prolactin gene fragment of PMp, Peking, and white Mojosari duck had homology 99\% with reference duck (Anas platyrhynchos) AB15811, 95\% with goose (Anser anser) DQ660983.1, 87\% with peacock (Pavo cristatus) AB605393.1, and 83\% with turkey (Meleagris gallopavo) AB605394.1 (Table 1).

The length of fragment prolactin gene of duck was $6.33 \mathrm{~kb}$ in length consisted of 5 exon and 4 introns which encodes 299 amino acid. Homology analysis of ducks prolactin was done by Kansaku et al. (2005). Kansaku et al. (2005) stated that ducks prolactin gene had similarity with chicken, turkey, and quail, i.e. $92.0 \%, 91.7 \%$ and $91.4 \%$, respectively. Within the mature peptide region duck prolactin cDNA had $93.5 \%$ and $92.5 \%$ similarity to chicken and turkey, respectively. The degree of amino acid sequence similarity of prolactin resulted from Northern hybridization analysis and comparison of the mRNA size. Analysis of northern blot hybridization showed that $1.45 \mathrm{~kb}$ mRNA transcript in duck was slightly longer than chicken and turkey.

Nucleotide composition in prolactin gene. The structure of duck prolactin was similar with chicken and turkey prolactin (Kansaku et al. 2005). The average composition of nucleotide base sequence of the prolactin gene in ducks showed that the composition $\mathrm{A}+\mathrm{T}$ percentage was higher than $\mathrm{C}+\mathrm{G}$ composition (Table 2). According to Muladno (2010), pair of A+T would be separated faster into a single strand compared to base $G+C$ pair, because $\mathrm{A}+\mathrm{T}$ pair had two hydrogen bonds, whereas $\mathrm{G}+\mathrm{C}$ base had three hydrogen bonds. This indicates that the exon area has $\mathrm{A}+\mathrm{T}$ composition more than $\mathrm{G}+\mathrm{C}$, because this area will be transcribed into a single strand.

The process of transcription requires a single stranded while DNA has a double thread bound by hydrogen bonds. Hydrogen bonds are weak bonds that are easily remove and reformed. As a result, couples DNA double thread easily breaks down into a single thread, because the nucleotide bases $\mathrm{A}+\mathrm{T}$ has two hydrogen bonds while the $\mathrm{G}+\mathrm{C}$ has three hydrogen bonds. $\mathrm{A}+\mathrm{T}$ has a weaker bond than $\mathrm{G}+\mathrm{C}$ so easily broken down by enzymes that play a role in the transcription process (Yusuf, 2001). Activation of prolactin receptor by prolactin binding can initiate the intracellular signaling cascades, including activation of the intacellular JAK2STAT5 signaling pathway (Brooks, 2012).

Detection mutation of prolactin gene. Partial intron and coding region of exon 4 was used for amplification and analysis SNP in sequence prolactin gene. The alignment analysis result showed that six SNP were found, the two transverse mutations were g.3941T $>\mathrm{G}$ and g.3975C $>\mathrm{A}$, transition mutation was g.4110T $>C$, deletion base adenine at position 3724 and $4031 \mathrm{bp}$ (INDEL $3724 \mathrm{~A}$ and indel 4031A) and an insertion base adenine at position 3939 bp (INDEL 3939A), specially for INDEL 3939A occured in all duck samples (Figure 3 and Table 3). Transverse mutation is a changing from purine base to pyrimidine base. Transition mutation occured because there was change from purine base to other purine base or pyrimidine base to other pyrimidine base (Nei, 1987). Yunita (2009) suggested that the type of deletion mutations occurred because of certain base pairs disappeared resulting in changes in the composition of nucleotide bases whereas type of insertion mutation occurred because of the insertion of particular bases.

Table 1. Homology analysis of duck prolactin base on BLAST

\begin{tabular}{lccc}
\hline \multirow{2}{*}{ Sample } & \multicolumn{3}{c}{ Homology (\%) } \\
\cline { 2 - 4 } & $\begin{array}{c}\text { PMp } \\
\text { Duck }\end{array}$ & $\begin{array}{c}\text { Peking } \\
\text { Duck }\end{array}$ & $\begin{array}{c}\text { White } \\
\text { Mojosari Duck }\end{array}$ \\
\hline $\begin{array}{l}\text { Duck (Anas platyrhynchos) } \\
\text { AB15811 }\end{array}$ & 99 & 99 & 99 \\
Goose (Anser anser) DQ660983.1 & 95 & 95 & 95 \\
Peafowl (Pavo cristatus) & 87 & 87 & 87 \\
AB605393.1 & & & \\
Turkey (Meleagris gallopavo) & 83 & 83 & 83 \\
AB605394.1 & & & \\
\hline
\end{tabular}

Table 2. The nucleotide base composition of duck prolactin

\begin{tabular}{lccccccc}
\hline \multirow{2}{*}{ Sample } & \multirow{2}{*}{$\begin{array}{c}\text { Total } \\
\text { sample }\end{array}$} & \multicolumn{6}{c}{ Average percentage (\%) } \\
\cline { 3 - 8 } & & $\mathrm{T}(\mathrm{U})$ & $\mathrm{C}$ & $\mathrm{A}$ & $\mathrm{G}$ & $\mathrm{T}+\mathrm{A}$ & $\mathrm{G}+\mathrm{C}$ \\
\hline Anas platyrhynchos & 1 & 31.80 & 18.50 & 31.70 & 18.10 & 63.50 & 36.60 \\
AB158611 & & & & & & & \\
PMp & 55 & 26.80 & 20.02 & 30.53 & 22.57 & 57.42 & 42.59 \\
White Mojosari & 10 & 26.88 & 20.27 & 30.48 & 22.38 & 57.36 & 42.65 \\
Peking & 9 & 26.90 & 20.20 & 30.49 & 22.38 & 57.39 & 42.58 \\
\hline
\end{tabular}


The region of exon 4 was existed at position 3753-3932 bp, so the analysis showed that all mutations occurred in intron area were intron 3 and intron 4. SNP INDEL 3724A was occurred in intron 3, whereas SNP INDEL 3939A, g.3941T>G, g.3975C>A, INDEL 4031A and g.4110T $>C$ was found in the region of intron 4 . Although intron did not participate in protein synthesis, the variance of intron might affect translation process (Li et al., 2011). Chang et al. (2012) reported that the analysis of the SNP g.3941T>G and g.3975C >A had a very significant association in reproductive traits $(\mathrm{P}<0.0001)$ to the fertility rate and $(\mathrm{P}<0.05)$ for percentage of hatchability eggs. In domestic breed of Gaoyou duck, T1326C mutation in intron 1 was associated with egg weight at the age of $30 \mathrm{wk}$ and proportion of double yolk (Li et al., 2009). In muscovy duck, two SNPs (g.3777T $>C$ and g.3785A $>$ G) were detected in exon 4 and found that there were significant differences between non-broodiness muscovies and broodines muscovies, muscovies and duck in genotypes frequencies ( $\mathrm{Wu}$ et al., 2008). In this study, we did not detect the above polymorphism sites, although six SNPs were detected in three native duck breeds (Peking, white Mojosari, and PMp duck). The result revealed that the duck prolactin gene was rich in polymorphisms.

SNP located in non-coding regions had effects on gene expression by affecting regulatory elements and some intronic SNPs actives cryptic splice sites, leading to alternative splicing (Alberobello et al. 2011). Introns had wide function in transcription initiation, transcription termination, genome organization, time delays in transcribed intron, transcription regulation, alternative splicing, expressing non codding RNAs, non-sense mediated decay in exon junction complex, nuclear export, cytoplasmic localization, and translation of yields (Chorev \& Carmel, 2012). There is no single mechanism by which introns enhance expression. In many cases, the mechanism is not yet known, but in those cases in which it had been revealed, introns seem to affect virtually any step of mRNA maturation, including transcription initiation, transcription elongation, transcription termination, polyadenylation, nuclear export, and mRNA stability.

Frequency of SNP. Single nucleotide polymorphisms (SNP) are the most often occurring manifestation of genetic variation in vertebrates genome. Approximately one of 1000 nucleotides in animal genome is expected to be a SNP site, accounting for more than $90 \%$ of all differences between animals. SNP identification and functional assessment is becoming an increasingly more important tool in molecular diagnostics and biology (Zhou et al., 2005). SNP is differences between DNA sequences from individuals compared. SNP can cover more than $90 \%$ of the genetic variation, so as to become a marker on the differences between the varieties of a species. In addition, the SNP is also far more abundant in number compared with other DNA markers (Matukumalli et al., 2006).

The results of the calculation of SNP frequencies on six mutations are presented in Table 4 . The analysis showed that the SNP frequencies at mutation INDEL 3724A, g.3941T>G, g.3975C>A, INDEL 4031A, and g.4110T $>\mathrm{A}$ were $2.70 \%, 25.67 \%, 39.19 \%, 32.43 \%$, and $14.86 \%$, respectively, whereas the mutation INDEL 3939A SNP frequency calculations showed the results of $100 \%$. Based on the literature, it could be concluded that the mutation of INDEL 3724A, g.3941T>G, g.3975C>A, INDEL 4031A, and g.4110T $>\mathrm{A}$ in ducks sample were polymorphic because there were two different types of SNP with percentage (> 1\%), while INDEL 3939A was monomorphic because there was only one type of SNP where calculation was $100 \%$ indicated INDEL 3939A occurred in all samples of ducks. Identification of genetic diversity in a population is used to identify and conserve the breeds of animal in the population identifier associated with a particular trait. Natural populations

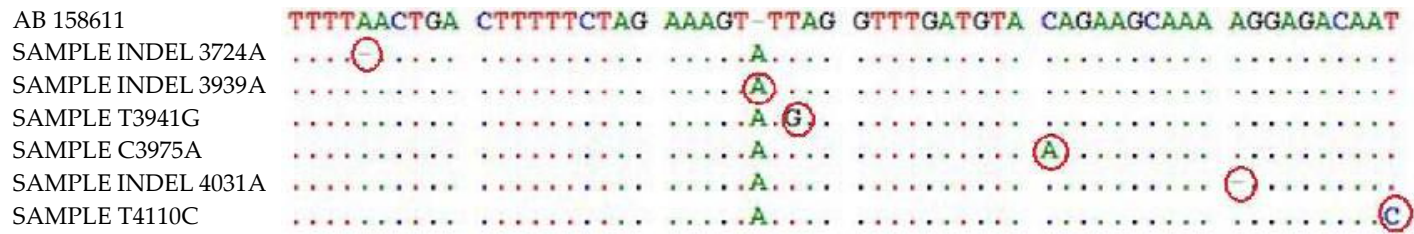

Figure 3. Result of alignment analysis sequence prolactin gene of Anas plathyrhyncos (AB 158611)

Table 3. Analysis of mutation detection of duck prolactin gene

\begin{tabular}{cccccc}
\hline \multirow{2}{*}{$\begin{array}{c}\text { Position } \\
(\mathrm{bp})\end{array}$} & Gene & Mutation & & \multicolumn{3}{c}{ Mutation } \\
\cline { 4 - 6 } & bank & type & PMp & Peking & $\begin{array}{c}\text { White } \\
\text { Mojosari }\end{array}$ \\
\hline 3724 & $\mathrm{~A}$ & Deletion & - & $\mathrm{A}$ & $\mathrm{A}$ \\
3939 & - & Insertion & $\mathrm{A}$ & $\mathrm{A}$ & $\mathrm{A}$ \\
3941 & $\mathrm{~T}$ & Tranverse & $\mathrm{T}>\mathrm{G}$ & & $\mathrm{T}>\mathrm{G}$ \\
3975 & $\mathrm{C}$ & Tranverse & $\mathrm{C}>\mathrm{A}$ & $\mathrm{C}>\mathrm{A}$ & $\mathrm{C}>\mathrm{A}$ \\
4031 & $\mathrm{~A}$ & Deletion & - & - & - \\
4110 & $\mathrm{~T}$ & Transition & $\mathrm{T}>\mathrm{C}$ & & $\mathrm{T}>\mathrm{C}$ \\
\hline
\end{tabular}

Note : - = deletion.
Tabel 4. Analysis of SNP frequency in prolactin gene exon 4

\begin{tabular}{llccc}
\hline No & Mutation & $\mathrm{n}$ & $\begin{array}{c}\text { Genotype } \\
\text { frequency }(\%)\end{array}$ & Annotation \\
\hline 1 & INDEL 3724A & 2 & 2.70 & Polymorphic \\
2 & INDEL 3939A & 74 & 100 & Monomorphic \\
3 & g.3941T $>$ G & 19 & 25.67 & Polymorphic \\
4 & g.3975C $>$ A & 29 & 39.19 & Polymorphic \\
5 & INDEL 4031A & 24 & 32.43 & Polymorphic \\
6 & g.4110T>A & 11 & 14.86 & Polymorphic \\
\hline
\end{tabular}

Note: Total sample were success in sequencing 74 sample; $\mathrm{n}=$ number of mutation. 
usually have a high genetic diversity. Information of genetic diversity of breeds will be very useful for security and sustainable food supply.

\section{CONCLUSION}

The alignment prolactin gene exon 4, partial intron 3 , and partial intron 4 find six SNP consisted of two transversion mutations, i.e. g.3941T $>\mathrm{G}$ and g.3975C $>\mathrm{A}$, transition mutation were g.4110T $>C$, two adenine base deletion occurs at position 3724bp (INDEL 3724A) and 4031bp (INDEL 34031) and adenine base insertion at position 3939 bp (INDEL 3939A). Analysis of SNP frequencies showed that mutation of INDEL 3724A, g.3941T>G, g.3975C>A, INDEL 4031A, and g.4110T>A were polymorphic and INDEL 3939A were monomorphic.

\section{ACKNOWLEDGEMENT}

This study was supported by the Indonesian Research Institute for Animal Production (IRIAP). Laboratory of Animal Breeding and Molecular Genetics, Faculty of Animal Science, Bogor Agricultural University provided the facilities for laboratory work and data analysis. We are also thankful to Ministry of Education and Culture for Beasiswa Unggulan (BU-DIKTI).

\section{REFERENCES}

Alberobello, A. T., V. Congedo, H. Liu, C. Cochran, M. C. Skarulis, D. Forrest, \& F. S. Celi. 2011. An intronic SNP in the thyroid hormone receptor beta gene is associated with pituitary cell-specific over-expression of a mutant thyroid hormone receptor beta2 (R338W) in the index case of pituitary-selective resistance to thyroid hormone. J. Transl. Med. 9:144. http://dx.doi.org/10.1186/1479-5876-9-144

Brooks, C. L. 2012. Molecular mechanisms of prolactin and its receptor. Endocr. Rev. 3: 504-525. http://dx.doi.org/10.1210/ er.2011-1040

Bu, G., C. Y. Wang, G. Cai, F. C. Leung, M. Xu, H. Wang, G. Huang, J. Li, \& Y. Wang. 2013. Molecular characterization of prolactin receptor (cPRLR) gene in chickens: gene structure, tissue expression, promoter analysis, and its interaction with chicken prolactin (cPRL) and prolactin-like protein (cPRL-L). Mol. Cell. Endocrinol. 370: 149-162. http:// dx.doi.org/10.1016/j.mce.2013.03.001

Chang, M. T., Y. S. Cheng, \& M. C. Huang. 2012. Association of prolactin haplotypes with reproductive traits in Tsaiya Ducks. Anim. Repro. Sci. 135:91- 96. http://dx.doi. org/10.1016/j.anireprosci.2012.08.024

Chorev, M. \& L. Carmel. 2012. The function of intron. Front. Genet. 3: 55. http://dx.doi.org/10.3389/fgene.2012.00055

Cui, J. X., H. L. Du, Y. Liang, X. M. Deng, N. Li, \& X. Q. Zhang. 2006. Association polymorphism in the promoter region of chicken prolactin with egg production. Poult. Sci. 85: 2631. http://dx.doi.org/10.1093/ps/85.1.26

FAO (Food and Agriculture Organization). 2013. Statistical yearbook 2013. http://www.fao.org/docrep/018/i3107e/ i3107e.PDF. [13 April 2014]

Hall, T. A. 1999. Bioedit: a user-friendly biological sequence alignment editor and analysis program for windows 95/98/NT. Nucl Acid Symp Ser. 41: 95-98.

IRIAP (Indonesian Research Institute for Animal Production). 2011. Characteristics Production of PMp Duck. http://balitnak.litbang.pertanian.go.id/ [8 October 2014]
Jiang, R. S., L. L. Zhang, Z. Y. Geng, T. Yang, \& S. S. Zhang. 2009. Single nucleotide polymorphisms in the $5^{\prime}$-flanking region of the prolactin gene and the association with reproduction traits in geese. S. Afr. J. Anim. Sci. 39: 83-87. http://dx.doi.org/10.4314/sajas.v39i1.43550

Kansaku, N., T. Ohkubo, H. Okabayashi, D. Guémené, U. Kuhnlein, D. Zadworny, \& K. Shimada. 2005. Cloning of duck PRL cDNA and genomic DNA. Gen. Comp. Endocr. 141: 39-47. Http://dx.doi.org/10.1016/j.ygcen.2004.11.017

Kansaku, N., G. Hiyama, T. Sasanami, \& D. Zadworny. 2008. Prolactin and growth hormone in birds: protein structure, gene structure and genetic variation. J. Poult. Sci. 45: 1-6. http://dx.doi.org/10.2141/jpsa.45.1

Li, H. F., W. Q. Zhu, K. W. Chen, T. J. Zhang, \& W. T. Song. 2009. Association of polymorphisms in the intron 1 of duck prolactin with egg performance. Turk. J. Vet. Anim. Sci. 33: 193-197.

Li, S., Y. Gong, X. Peng, Y. Feng, W. Yu, Z. Liang, \& C. Wang. 2011. Polymorphism of the prolactin gene and its association with egg production traits in native Chinese ducks. S. Afr. J. Anim. Sci. 41: 63-70.

Matukumalli, L. K., J. J.Grefenstette, D. L. Hyten, I. Y. Choi, P. B. Cregan, \& C. P. Van Tassell. 2006. Application of machine learning in SNP discovery. BMC Bioinformatics 7:4. http://dx.doi.org/10.1186/1471-2105-7-4

Muladno. 2010. Teknologi Rekayasa Genetika. Edisi kedua. IPB Press, Bogor.

Nei, M. 1987. Molecular Evolutionery Genetics. Columbia University Press, New York.

Nei, M. \& S. Kumar. 2000. Molecular Evolution and Phylogenetics. Oxford University Press. Inc., New York.

Sambrook, J., E. F. Fritsch, \& T. Maniatis. 1989. Molecular Cloning: A Laboratory Manual. 2nd Ed. Cold Spring Harbour Laboratory Press, New York.

Tamura, K., J. Dudley, M. Nei, \& S. Kumar. 2007. MEGA4: Molecular Evolutionary Genetics Analysis (MEGA) software version 4.0. Mol. Biol. Evol. 24:1596-1599. http://dx.doi. org $/ 10.1093 / \mathrm{molbev} / \mathrm{msm} 092$

Tataurov, A. V., Y. You, \& R. Owczarzy. 2008. Predicting ultraviolet spectrum of single stranded and double stranded deoxyribonucleic acids. Biopys Chem. 133: 66-70. http:// dx.doi.org/10.1016/j.bpc.2007.12.004

Wang, J., S. S. Hou, W. Huang, X. G. Yang, X. Y. Zhu, \& X. L. Liu. 2009. Molecular cloning of prolactin receptor of the Peking duck. Poult. Sci. 88: 1016-1022. http://dx.doi. org/10.3382/ps.2008-00192

Wang, C., Z. Liang, W. Yu, Y. Feng, X. Peng, Y. Gong, \& S. Li. 2011. Polymorphism of the prolactin gene and its association with egg production traits in native Chinese Ducks. S. Afr. J. Anim. Sci. 41: 64-69. http://dx.doi.org/10.4314/sajas. v41i1.66044

Wheeler, D. \& M. Baghwat. 2007. BLAST Quick Start Example Driven Web-Based BLAST Tutorial in Comparative and Genomic. In: N. H. Bergman. Comparative Genomics. Totowa, New Jersey. p. 149.

Wu, X., A. Li, S. K. Wang, H. Wang, H. Y. Jia, \& G. Y. Wang. 2008. Correlation analysis between nucleotide polymorphism of the prolactin exon 5 and broodines in duck. Fujian J. Anim. Husband. Vet. 30:6-9.

Yunita, R. 2009. Pemanfaatan variasi somaklonal dan seleksi in vitro dalam perakitan tanaman toleran cekaman abiotik. Jurnal Litbang Pertanian. 28: 143.

Yusuf, M. 2001. Genetika 1: Struktur dan Ekspresi Gen. CV Sagung Seto, Jakarta.

Zhou, X., N. P. Rao, S. W. Cole, S. C. Mok, Z. Chen, \& D. T. Wong. 2005. Progress in concurrent analysis of loss of heterozygosity and comparative genomic hybridization utilizing high density single nucleotide polymorphism arrays. Cancer Genet. Cytogenet. 159: 53-57. http://dx.doi. org/10.1016/j.cancergencyto.2004.09.014 